\title{
ОЦЕНКА ПРИРОДНОЙ РЕКРЕАЦИОННОЙ СИСТЕМЫ В АРЕАЛАХ НЕДОСТУПНОСТИ
}

\author{
(С) 2020 г. А. Ю. Королев* \\ Пермский государственный национальный исследовательский университет, Пермь, Россия \\ *e-mail:korolev@psu.ru \\ Поступила в редакцию 24.11.2019 г. \\ После доработки 17.01.2020 г. \\ Принята к публикации 30.01.2020 г.
}

\begin{abstract}
На ненаселенных территориях выделяются полюсы недоступности - точки, максимально удаленные от любой инфраструктуры. Вокруг них формируются ареалы недоступности, со всех сторон ограниченные разными инфраструктурными объектами. Полюсы недоступности можно выделять разного масштаба: муниципального, регионального, национально-континентального и планетарного. В каждом из них складывается особенная система организации рекреации. Совокупность разных по функциям элементов, определяющих рекреацию в ареалах недоступности, составляет природную рекреационную систему. Она отражает взаимодействие туристов и рекреантов, ненаселенных природных территорий и контролирующих органов, осуществляющих регистрацию, поиск и спасение туристских групп. В статье предложена формула для вычисления рекреационного потенциала природной рекреационной системы, учитывающая хозяйственную деятельность, доступность, климат, рельеф, пейзажную привлекательность. Изучены ареалы недоступности микроуровня, окружающие город Пермь. Их рекреационный потенциал, рассчитанный по данной формуле, соответствует среднему уровню. Рекреационный потенциал ареала полюса недоступности Пермского края соответствует среднему и высокому уровням. Предложенная формула и использование ГИС-технологий позволяют определить, где целесообразно развивать рекреационную и туристскую деятельность и создавать охраняемые природные территории.
\end{abstract}

Ключевые слова: полюс недоступности, туризм, рекреация, территориальная рекреационная система, природные территории, Пермский край, пейзажная привлекательность, хозяйственная деятельность

DOI: $10.31857 / \mathrm{S} 2587556620030085$

\section{ТЕОРИЯ ВОПРОСА И ИЗУЧЕННОСТЬ В РОССИИ И МИРЕ}

Размещение населения в мире далеко не однородно. Наряду с крайне перенаселенными территориями имеется огромное количество совершенно ненаселенных. Как правило, последние по мере удаления от инфраструктуры или от побережья становятся все более труднодоступными, появляются места, практически не посешаемые человеком. При изучении таких недоступных объектов важно знать, где они сформировались, по какой причине, как их можно использовать. Несомненно, при гармоничном развитии общества такие территории всегда должны быть. В них можно создавать заповедники или национальные парки, они должны быть местом рекреации людей, а также участками сохраненной дикой природы, в которых влияние человека минимально.

Понимать под недоступностью можно разные аспекты. Если это просто очень труднодоступное место, то полюсом недоступности Земли будет вершина горы Эверест. Нас же интересует нечто другое, а именно - удаленность от населенных пунктов и инфраструктуры [16]. Полюс недостуnности - это точка, максимально удаленная от инфраструктуры в конкретной географической области. Вокруг него формируется ареал недостуnности, который может иметь различную форму. Она зависит от многих факторов: рельефа местности, расположения транспортных путей, месторождений полезных ископаемых, исторического расселения людей, климатических условий, высоты над уровнем моря и т.д.

П.Г. Талалай и А.Н. Марков, И.А. Мельников, Т.А. Адашова считают, что полюс недоступности это глобальное понятие. По их мнению, северный полюс недоступности находится в арктических льдах на максимальном расстоянии от любой суши. Южный полюс недоступности находится в Восточной Антарктиде, на расстоянии 878 км от географического Южного полюса, и попасть на него намного труднее, чем на географический 
[1, 19, 32]. Они же выделяют континентальные полюсы недоступности - точки на максимальном удалении от всех океанов. Хотя нам представляется более правильным выделять полюсы недоступности, расположенные на максимальном удалении от инфраструктуры, причем их недоступность может увеличить сильно пересеченный рельеф местности и большая высота над уровнем моря. Соответственно, континентальным полюсом недоступности будет точка на континенте, максимально удаленная от инфраструктуры.

За рубежом авторы подобных исследований изучают затраты времени на поездки в крупные города из всех окружающих их населенных пунктов и таким образом вычисляют самые труднодоступные из них; там проживает самое социально незащищенное население [47, 49]. Также исследуются не имеющие инфраструктуры территории с целью их охраны от использования в хозяйственной деятельности [45], лесные территории (с помощью составления карт высокого разрешения) [44], усиление антропогенной нагрузки, угрожающее объектам природного наследия [41]. Проводится геопространственный анализ ненаселенных территорий [43].

Как уже говорилось выше, термин полюс недоступности воспринимается как глобальное понятие, мы же хотим наполнить его новым смыслом и сделать применимым для территорий разного масштаба.

Рассмотрим полюсы недоступности природного происхождения. Их можно выделять разного уровня, от глобальных (планетарных) до мелких (муниципальных). Для удобства использования можно упорядочить терминологию. Самые маленькие, такие, от которых до ближайшего объекта инфраструктуры от 1 до 10 км, можно назвать полюсами недоступности микроуровня. Они, как правило, являются муниципальными, их можно найти практически в каждом регионе России. Такие участки природной среды будут служить основным местом однодневной рекреации городского населения и, соответственно, будут наиболее часто посещаемыми. Вокруг крупных городов иногда можно выделить несколько таких территорий, окружающих город с разных сторон и ограниченных дорогами, промышленными или сельскохозяйственными объектами, окраинными жилыми кварталами.

Такое расположение полюсов недоступности микроуровня очень хорошо соотносится с теорией поляризованного ландшафта Б.Б. Родомана [28], которую в дальнейшем развивает А.И. Зырянов [12]. Полюсы недоступности микроуровня обычно со всех сторон окружены инфраструктурой или какими-либо хозяйственными территориями, превышающими их по размерам. Концентрация урбанизированных объектов должна соче- таться с природными объектами, причем это переплетение разнообразных по функциям территорий должно быть довольно частым. Крупные города должны иметь на своих окраинах, а желательно быть полностью окруженными руральными или лесными территориями. Это необходимо для предоставления населению, ведущему напряженный образ жизни, доступа к наиболее полноценной рекреации в природных условиях без особых временны́х затрат.

Любой полюс недоступности - это всего лишь точка, но вокруг этой точки всегда образуется ареал недоступности. Причем чем ближе к полюсу недоступности, тем более нетронутая и красивая природа, а чем дальше - тем больше встречается проявлений антропогенного влияния на природную среду, снижается эстетическое качество территории и ее рекреационные возможности.

С одной стороны, кажется странным, что термин “полюс недоступности” применяется к такому незначительному расстоянию, как 1-10 км. Тем не менее в некоторых регионах, особенно в Московской области и других субъектах европейской части России, даже такие небольшие участки будут самыми недоступными местами, если вокруг непрерывно расположены различные инфраструктурные объекты и сельскохозяйственные угодья. При этом до полюсов недоступности микроуровня нельзя добраться на транспортном средстве, а можно только активными способами передвижения. В большинстве регионов России таковыми полюсами недоступности будут являться городские и пригородные леса, где только и есть возможность для осуществления однодневной рекреации городского населения в природной среде.

В качестве примера можно рассмотреть полюсы недоступности микроуровня, окружающие город Пермь. Каждый из них образует ареалы недоступности, при этом расстояние от точки полюса до краев ареала будет от 1 до 10 км. Всего вокруг Перми можно выделить 8 полюсов недоступности с ареалами. Интересно, что один из них Черняевский лес - целиком расположен на территории города и со всех сторон окружен жилыми кварталами (рис. 1).

Следующими по размеру будут полюсы недоступности мезоуровня. Для большинства стран, где они имеются, они являются региональными. При этом расстояние от полюсов до ближайших объектов инфраструктуры - от 10 до 100 км. Если полюсы недоступности микроуровня можно найти почти во всех странах мира, то полюсы недоступности мезоуровня присутствуют далеко не везде. Что касается Российской Федерации, то они встречаются все же в большинстве регионов, даже в европейской части страны. Чаще всего такие полюсы расположены на границе двух и более 


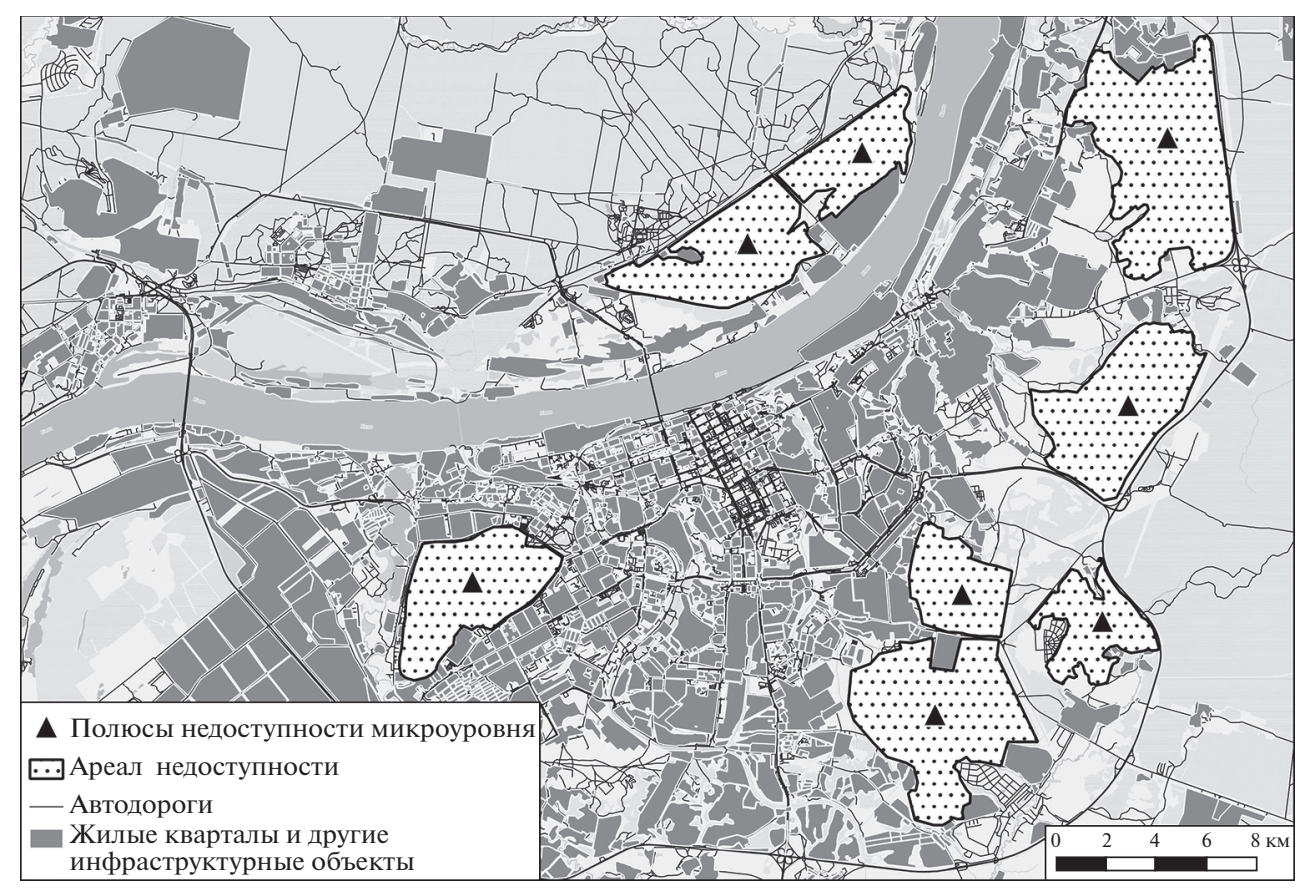

Рис. 1. Ареалы и полюсы недоступности микроуровня в окрестностях города Перми.

регионов. Это происходит потому, что освоение территории всегда начинается от центра (столицы) региона и направляется к его периферии, достигая минимального уровня у его границы.

В отличие от полюсов недоступности микроуровня полюса мезоуровня чаще всего сами окружают населенные пункты и другие инфраструктурные объекты со всех сторон. Края их могут быть изрезанными, в них могут вдаваться дороги или какие-либо хозяйственные территории. В качестве примера можно привести полюс недоступности Пермского края (самую труднодоступную точку региона), ареал которого представляет собой обширные ненаселенные территории трех соседних регионов: Пермского края, Республики Коми и Свердловской области [17]. Есть смысл исследовать именно Пермский край, потому что он средний по размерам, учитывая все регионы России, расположен в срединной части страны, соответственно, может отображать средние показатели по разным исследуемым вопросам.

Наиболее удаленная точка от всех населенных пунктов Пермского края находится на северо-востоке региона в долине p. Вишера, на 5.1 км западнее ее русла, на высоте 332 м над ур. м. (рис. 2). Ее координаты: $61^{\circ} 21^{\prime} 29.12^{\prime \prime}$ с.ш. и 58 $47^{\prime} 43.98^{\prime \prime}$ в.д. Полюс недоступности расположен на одинаковом расстоянии - 68.5 км - от поселков Ушма (Свердловская область), Вижай и Велс (Пермский край). Площадь ареала недоступности этого полюса составляет более 22 тыс. км².
В Пермском крае из-за условий расселения, развития инфраструктуры и географических особенностей, могут быть и другие полюсы недоступности мезоуровня, т.е. регионального масштаба, имеющие значение только для данного региона. При этом их ареалы недоступности будут не такими значительными, а сами ненаселенные территории - это зона многодневной рекреации.

Следующий уровень полюсов недоступности (с соответствующим огромным ареалом) еще более высокого ранга - макроуровень. Полюса будут национально-континентального масштаба, потому что таковые встречаются далеко не во всех странах, но присутствуют на всех континентах. Диапазон размеров таких полюсов недоступности от самой удаленной точки до ближайшего населенного пункта составит от 100 до 500 км.

Полюсом недоступности Евразии является территория, расположенная на плато Чангтан на Северном Тибете. От этой точки до ближайших населенных пунктов - до 500 км во все стороны: с севера это населенные пункты на юге пустыни Такла-Макан и в предгорьях Кунь-Луня; с юга редкие поселки на Северной тибетской трассе, соединяющей город Амдо на востоке с городом Али на западе; на западе и востоке населенные пункты расположены еще дальше. Протяженность ненаселенных территорий здесь составляет 800 км с севера на юг и более 1000 км с запада на восток.

Такие гигантские ареалы недоступности тоже используются в многодневной рекреации, но, ко- 


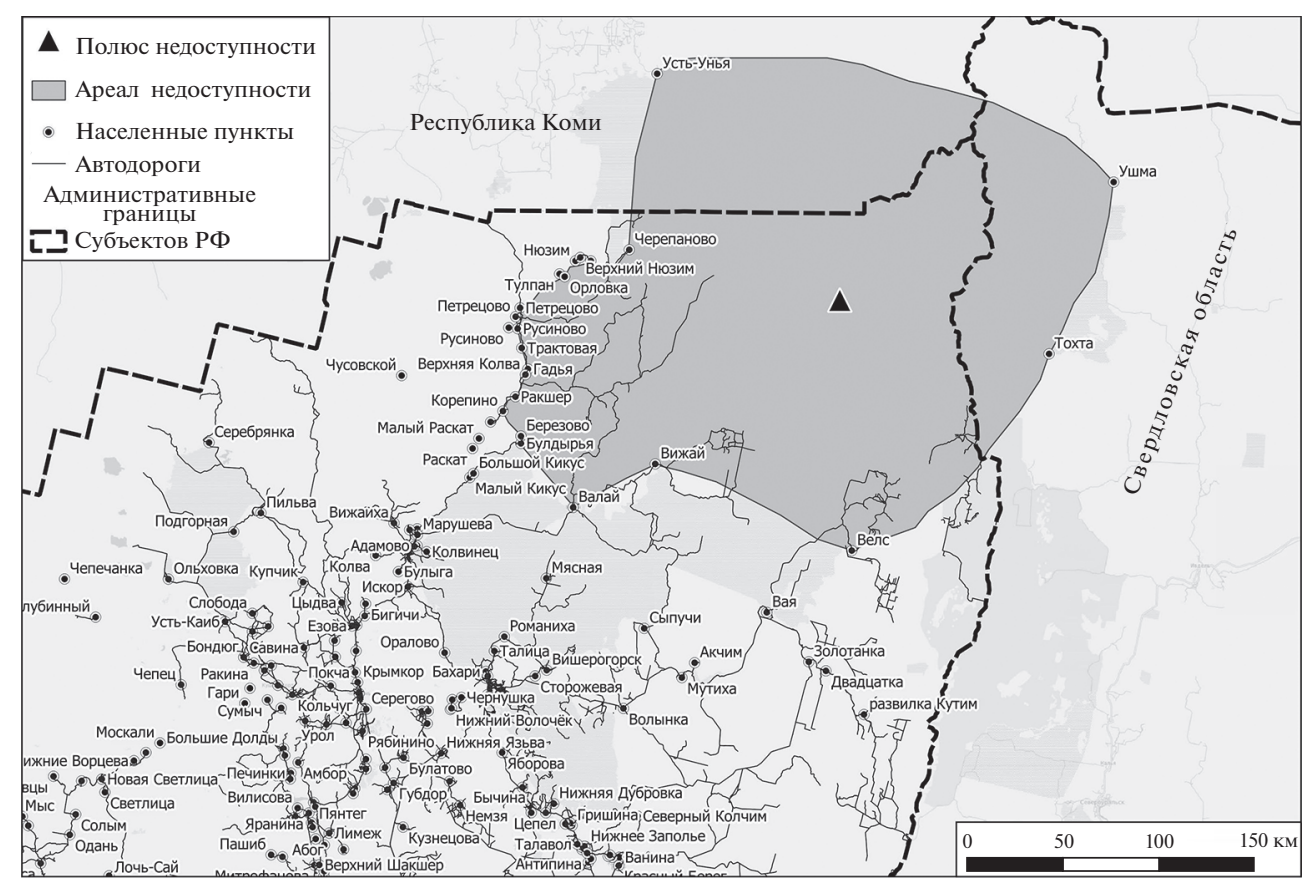

Рис. 2. Ареал и полюс недоступности Пермского края (мезоуровня).

нечно, не полностью и в основном в определенных, наиболее аттрактивных местах. Сами полюсы недоступности посещаются очень редко, главным образом со спортивными или исследовательскими целями. Часто на национально-континентальных полюсах недоступности присутствуют охраняемые природные территории - национальные парки и заповедники. В них могут быть созданы специальные туристские маршруты и экологические тропы.

На территории Российской Федерации также выделяется полюс недоступности. Он расположен в Эвенкии, южнее плато Путорана, на водоразделе между оз. Виви и Тембенчи. Его координаты - 66³6 $09.04^{\prime \prime}$ с.ш. $94^{\circ} 40^{\prime} 20.70^{\prime \prime}$ в.д., а высота над уровнем моря составляет 949 м. Вокруг российского полюса недоступности формируется ареал недоступности - второй по размеру в Евразии. Он оконтурен с севера населенными пунктами на р. Хета (поселки Усть-Авам, Волочанка и Катырык); с запада - городом Норильск, поселками Талнах и Хантайское озеро, селом Туруханск; с юга - поселками в долине р. Нижняя Тунгуска (Ногинск, Тутончаны, Учами, Нидым и Тура); с востока - поселками Ессей и Чиринда. Максимальная протяженность ненаселенных территорий составляет здесь 840 км с севера на юг (от поселка Катырык до поселка Учами) и 600 км с запада на восток (от села Туруханск до поселка Тура). Самое узкое место данного ареала недоступности - 445 км (от поселка Хантайское озеро до поселка Чиринда). По площади этот ареал в два раза меньше ареала на Северном Тибете. Российский полюс недоступ- ности расположен в южной части выделенного ареала недоступности и равноудален на 270 км от трех окружающих его населенных пунктов: поселка Хантайское озеро с северо-запада, Чиринда с северо-востока и Тутончаны с юга.

Можно выделить еще более крупные полюсы недоступности, которые будут относиться к мегауровню, - полюсы планетарного масштаба. Размеры таких огромных ненаселенных территорий должны быть более 500 км от центра до ближайшей инфраструктуры (и без верхней границы). Такие полюса недоступности имеют значение для многих государств, и их можно выделить несколько.

Полюс недоступности северного полушария (имеется в виду территория суши), т.е. самая удаленная от инфраструктуры точка северного полушария, находится в Гренландии. Его ареал недоступности намного превышает по размеру названные выше ненаселенные территории в Тибете и в азиатской части России. Площадь ненаселенных пространств огромна - это весь ледовый панцирь Гренландии. Населенные пункты имеются только по берегам острова, где нет льда. Ненаселенные территории простираются на 2 тыс. км с севера на юг, с запада на восток их протяженность составляет от 300 км в южной части острова до 1000 км в северной. Полюс недоступности находится в северной части. От него до ближайших населенных пунктов - до 700 км. Это дальше, чем до ближайшего берега острова, поскольку в северной части населенные пункты имеются только с западной 
стороны (поселок Туле). Самый северный поселок восточного берега - Иттокортоормиит - расположен примерно в середине острова.

Изучение уровней полюсов недоступности и образуемых ими ареалов недоступности показывает, что все они могут использоваться в рекреационной деятельности. Конечно, рекреационное использование территории будет разным в зависимости от уровня полюса и ареала недоступности.

Новое понятие, необходимое для более полноценного изучения данного явления - рекреационного использования ареалов недоступности, т.е. ненаселенных природных территорий, можно обозначить природная рекреационная система. При этом оно не противоречит общепринятому понятию территориальной рекреационной системы (ТРС), разработанному В.С. Преображенским, Ю.А. Ведениным, И.В. Зориным, И.Л. Мухиной и другими авторами [26, 27, 34], а дополняет его.

Природная рекреационная система (ПРС) - это совокупность разных по функциям элементов, определяющих рекреацию в ареалах недоступности. Уровень ареала недоступности определяет, какая рекреация возможна на его территории: однодневная или многодневная. Многодневная рекреация в природной среде чаще всего представляет собой активное туристское путешествие. В свою очередь вид этого путешествия зависит от сезона года, характеристики местности и наличия объектов, представляющих интерес для туристов.

ПРС затрагивает только природную составляющую ТРС, при этом, чем меньше антропогенное влияние, тем выше его рекреационные возможности. ПРС отражает взаимодействие туристов и рекреантов, ненаселенных природных территорий и контролирующих органов, осуществляющих регистрацию, поиск и спасение туристских групп на ненаселенных территориях. Это более простая схема, чем ТРС, отображающая рекреационную деятельность в природных условиях, с минимизацией воздействий человека на природу.

По В.С. Преображенскому и другим авторам, территориальная рекреационная система - это социальная географическая система, состоящая из взаимосвязанных подсистем: природных и культурных комплексов, инженерных сооружений, обслуживающего персонала и отдыхающих (рекреантов), характеризующаяся функциональной и территориальной целостностью. В ПРС складываются определенные типы рекреации: активный отдых и природоориентированный туризм, который может быть активным, спортивным, экстремальный и др. Для существования ПРС не нужно культурных комплексов, инженерных сооружений и обслуживающего персонала. ПРС может формироваться самостоятельно на аттрактивной природной территории, доста- точно доступной для формирования потока туристов и рекреантов.

Рекреационная и туристская деятельность в ПРС слабо регулируется законодательными актами государства и правилами местных ООПТ разного типа. Если участок ПРС расположен на территории хорошо освоенного национального парка, то там возможно наличие ТРС с большим количеством подсистем. В этом случае присоединятся: материальная база, рекреационная инфраструктура, обслуживающий персонал и орган управления. Каждая из этих подсистем выполняет свои функции. В настоящее время все чаще встречаются варианты планирования развития не отдельных туристских объектов, а их сочетаний, появляется стремление к формированию туристско-рекреационной среды на обширных пространствах, в том числе ненаселенных [13].

Особенности использования территории ареалов недоступности разного уровня рассмотрены в табл. 1. Для определения возможностей использования территории для целей рекреации и туризма нужно разработать систему оценки, отражающей ситуацию по комплексу факторов. Конечно, ранее было проведено много исследований, и первыми в решении этой проблемы были отечественные ученые - Ю.А. Веденин и Н.Н. Мирошниченко [6]. В их исследовании дается детальная оценка природных условий организации отдыха и туризма, при этом степень благоприятности каждого природного фактора оценена в баллах, а отдельных природных выделов - суммой баллов. Чем более благоприятным является данный фактор в пределах данного выдела, тем выше балл оценки; чем выше сумма баллов, тем благоприятнее условия данной территории для отдыха. Отдых подразделяется авторами на зимний и летний. Также подобными исследованиями занимались В.С. Преображенский [34], Н.С. Мироненко и И.Т. Твердохлебов [20]. А.Г. Исаченко указывает на задачи ландшафтоведения в области рекреационных исследований, которые сводятся к изучению рекреационного потенциала геосистем и воздействия на них рекреационных нагрузок [14]. Балльные шкалы для географических исследований использовал и Д.Л. Арманд [3]. Сегодня балльные методики оценки рекреационного потенциала территории видоизменяются и дополняются такими исследователями, как Ю.А. Худеньких [38], С.Э. Мышлявцева [22], А.А. Сафарян [29, 30], В.П. Чибилёва [39].

Ю.О. Тхамитлокова выделяет 4 типа подходов к оценке природного потенциала территории для целей туризма и рекреации [35].

1. Медико-биологическая оценка, включающая анализ климатических, бальнеологических, водных, растительных, рекреационных ресурсов. 
Таблица 1. Полюсы и ареалы недоступности по уровням и параметрам использования территорий

\begin{tabular}{|c|c|c|c|c|}
\hline Критерий & Микроуровень & Мезоуровень & Макроуровень & Мегауровень \\
\hline Масштаб & Муниципальный & Региональный & $\begin{array}{l}\text { Национально-кон- } \\
\text { тинентальный }\end{array}$ & Планетарный \\
\hline $\begin{array}{l}\text { Расстояние до инфра- } \\
\text { структуры, км }\end{array}$ & $1-10$ & $10-100$ & $100-500$ & Более 500 \\
\hline $\begin{array}{l}\text { Особенности рекреа- } \\
\text { ционной деятельности }\end{array}$ & Рекреация & $\begin{array}{l}\text { Активный и спор- } \\
\text { тивный туризм }\end{array}$ & $\begin{array}{l}\text { Спортивный туризм, } \\
\text { экспедиции }\end{array}$ & Экспедиции \\
\hline $\begin{array}{l}\text { Примерная продолжи- } \\
\text { тельность рекреацион- } \\
\text { ной деятельности }\end{array}$ & 1 день, без ночевки & $\begin{array}{l}2 \text { дня - несколько } \\
\text { недель }\end{array}$ & $\begin{array}{l}\text { Несколько недель - } \\
\text { несколько месяцев }\end{array}$ & $\begin{array}{l}\text { Несколько недель - } \\
\text { несколько месяцев }\end{array}$ \\
\hline Частота посещения & Ежедневно & $\begin{array}{l}\text { Выходные дни и во } \\
\text { время наилучших } \\
\text { климатических усло- } \\
\text { вий }\end{array}$ & Редко & $\begin{array}{l}\text { Почти не посеща- } \\
\text { ются }\end{array}$ \\
\hline Район посещения & По всей площади & $\begin{array}{l}\text { Наиболее аттрактив- } \\
\text { ные места }\end{array}$ & $\begin{array}{l}\text { Окраинные и наибо- } \\
\text { лее аттрактивные } \\
\text { места }\end{array}$ & $\begin{array}{l}\text { Только по маршру- } \\
\text { там экспедиций }\end{array}$ \\
\hline
\end{tabular}

Этот тип отражает влияние природных факторов на организм человека (например, $[6,18,36])$.

2. Технологическая оценка, отражающая взаимодействие человека и природной среды, “технологии рекреационной деятельности и техники” (см. [11, 15, 23]).

3. Психолого-эстетическая оценка, показывающая эмоциональное восприятие отличительных черт природного ландшафта и его компонентов на человека (в том числе $[9,33,48])$.

4. Экономическая оценка, возможная только для тех рекреационных ресурсов, экономический эффект которых можно измерить: минеральных вод, лечебных грязей, природных национальных парков (см. [5, 8]).

Несмотря на уже имеющиеся методики балльной оценки рекреационного потенциала природных территорий, мы предлагаем свою, которая учитывает разносторонние факторы и, по нашему мнению, проще в исполнении.

\section{МЕТОДИКА ОЦЕНКИ ПОЛЮСОВ И АРЕАЛОВ НЕДОСТУПНОСТИ ДЛЯ ОРГАНИЗАЦИИ ТУРИЗМА И РЕКРЕАЦИИ}

Наибольшими рекреационными свойствами будут обладать те территории ПРС, которые расположены в ареалах недоступности мезоуровня или на окраинах ареалов макроуровня. Так происходит потому, что ареалы недоступности микроуровня расположены в непосредственной близости от населенных пунктов, в них наблюдаются проявления хозяйственной деятельности и отрицательное воздействие посещений большого ко- личества рекреантов. Ареалы мезоуровня сочетают в себе наиболее качественные показатели по этому фактору. Они относительно доступны для населения и в то же время могут в меньшей степени быть задействованы в хозяйственной деятельности. Кроме этого, важно, чтобы климат был более комфортным хотя бы несколько месяцев в году, но чем продолжительнее этот период, тем выше рекреационные возможности территории.

Учитывая множество факторов, можно составить формулу оценки рекреационного потенциала природной рекреационной системы (Рпрс), которая вычисляется из совокупности следующих критериев:

1. Хозяйственная деятельность (Х). При этом не учитывается созданная туристская и рекреационная инфраструктура, присутствие которой не снижает рекреационные возможности ПРС, а в некоторых случаях увеличивает их. Максимальное значение этого критерия - полное отсутствие признаков хозяйственной деятельности или наличие только туристской инфраструктуры.

2. Доступность (Д). Должно быть наличие наземных путей сообщения хорошего качества, чтобы затраты времени от крупных населенных пунктов, где жители больше всего нуждаются в природной рекреации, не превышали несколько часов, т.е. чтобы посещение таких ареалов недоступности в выходные дни было рентабельным. Это будет максимальное значение критерия.

3. Климат (К). Климатические условия должны позволить совершать рекреацию в исследуемых ареалах не только спортивным или экстремальным туристам, но и широким массам населения. Максимальное значение достигается при 
возможности круглогодичной рекреации. Это зависит от широты местности (которая прямым образом влияет на продолжительность светового дня, температуру воздуха), высоты местности над уровнем мирового океана, близости к побережью. Также на качество этого критерия влияет среднее количество дней в году с плохой погодой, ветрами и циклонами.

4. Рельеф (Р). Рельеф местности должен быть довольно безопасным и удобным для организации путешествий, а абсолютная высота - в пределах от 1000 до 3000 м. Это максимальное значение критерия ввиду того, что более высокие местности уже не могут иметь рекреационные свойства из-за сниженного количества кислорода в возду$\mathrm{xe,} \mathrm{a} \mathrm{более} \mathrm{низкие} \mathrm{только} \mathrm{в} \mathrm{редких} \mathrm{случаях} \mathrm{имеют}$ красивые пейзажи. Этому показателю более всего соответствует зона среднегорья.

5. Пейзажная привлекательность (П). Максимальным эстетико-ресурсным потенциалом обладают именно горные ландшафты. Такого мнения придерживаются авторы многих работ, в том числе $[9,21,25,31,37,42,46]$. Д.А. Дирин объясняет это повышенной степенью ландшафтного разнообразия в горах. В связи с наложением зональных и азональных факторов дифференциации ландшафтной сферы (широтной и высотной поясности, секторности, барьерности, экспозиционности склонов, инверсионных процессов, активности гравитационных сил и т.д.) даже на небольшой территории здесь сосредотачивается огромное количество контрастных вариаций пейзажей. Это несомненное преимущество горных ландшафтов перед равнинными.

За основу оценки пейзажной привлекательности взята методика Д.А. Дирина [10] с изменениями и компилятивным упрощением. При этом учитываются следующие показатели: пейзажное разнообразие, цветовая гамма, пейзажно-композиционное устройство, наличие и количество леса в ландшафте, наличие выделяющихся (символических) объектов в пейзаже.

По пейзажному разнообразию менее привлекательны однородные и монотонные пейзажи, состоящие из одинаковых компонентов: геоморфологических (скалы, морены, осыпи, галечник, курумники), гидрологических (линейные и площадные водные объекты), гляциологических (ледники, снежники), биологических (древесная, кустарниковая и травянистая растительность). Более привлекательны разнообразные пейзажи, состоящие из многих компонентов разных видов [40].

Цветовая гамма - исключительно важный объективный показатель эстетичности ландшафта. Наибольшее значение для восприятия имеют цветовые аспекты пейзажа, но значительную роль играют и цветовые вкрапления. Влияние разных цветов на восприятие человеком и в це- лом на его психику достаточно хорошо изучено в психологии и психофизиологии. Пейзажеобразующие цвета ранжированы по характеру их эстетического воздействия. При этом наименее аттрактивны пейзажи из черного и серого цветов, далее - из светло-серого, коричневого и палевого, более аттрактивны - из голубого и зеленого цветов, а самыми привлекательными - из бирюзового, желтого, белого, розового, фиолетового, синего, оранжевого, красного [2, 4, 7]. Большое значение имеет сезон года, в зависимости от которого меняются цвета.

Пейзажсно-композиционное устройство. Наиболее живописны многосюжетные (панорамные) и многоплановые виды с пейзажными кулисами. Менее живописны мало- или одноплановые виды с небольшим количеством сюжетов, без пейзажных кулис [24]. Наличие и количество леса в ландшафте - это тоже комплексный показатель привлекательности. Оптимальная степень залесенности - от 30 до 70\%. Такие пейзажи не противоречат критерию обзорности, часто формируют обширные панорамы [9]. Наличие выделяющихся (символических) объектов в пейзаже. Такие объекты являются доминантой, вокруг которых структурируются остальные элементы пейзажа. Выделяющимися объектами могут быть выдающиеся вершины, водопады, озера, ледники. При этом имеет значение характер объекта, его размер и расстояние до него. Большее расстояние до объекта может компенсироваться его более крупными размерами и яркими цветами [9].

В формуле оценки рекреационного потенциала ПРС не учитываются культурные факторы, потому что они присутствуют далеко не на всех природных территориях, а если таковые имеются, то субъективны. Не всем туристам могут быть интересны какие-либо культурные объекты, традиционная культура коренного населения и сакральные места, расположенные в ареалах недоступности по маршруту их путешествия. Надо отметить, что граница ареалов недоступности, в которых осуществляется туристское путешествие, часто формируется объектами традиционной культуры, а именно - небольшим населенным пунктам, где проживает коренное население. Например, поселки Верхняя Гутара и Алыгджер в Тофаларии, где живут тофалары, поселки Тресколье и Ушма на Северном Урале, где проживают манси. Именно от этих населенных пунктов обычно и начинаются туристские маршруты. Но поскольку этот фактор субъективный, временный и не обязательный, то в нашей методике мы его в расчет не берем.

Таким образом, рекреационный потенциал ПРС, вычисляется по следующей формуле:

$$
\text { Рпрс }=\text { X }+ \text { Д }+ \text { K + P }+ \text { П. }
$$


Таблица 2. Критерии оценки рекреационного потенциала ПРС

\begin{tabular}{|c|c|c|c|c|}
\hline Критерий & 1 балл & 2 балла & 3 балла & 4 балла \\
\hline $\begin{array}{l}\text { Хозяйственная } \\
\text { деятельность }\end{array}$ & $\begin{array}{l}\text { Недавние сильные } \\
\text { изменения природ- } \\
\text { ной среды (до } 5 \text { лет), } \\
\text { вызывающие нега- } \\
\text { тивное впечатление }\end{array}$ & $\begin{array}{l}\text { Более ранние хозяй- } \\
\text { ственные воздействия } \\
\text { на природную среду } \\
\text { (5-30 лет). Произо- } \\
\text { шло частичное восста- } \\
\text { новление }\end{array}$ & $\begin{array}{l}\text { Давние воздействия } \\
\text { на природную среду } \\
\text { (более } 30 \text { лет). Вто- } \\
\text { ричные хвойные леса, } \\
\text { первичные леса с } \\
\text { незначительным воз- } \\
\text { действием }\end{array}$ & $\begin{array}{l}\text { Отсутствие хозяйствен- } \\
\text { ной деятельности. } \\
\text { Возможно наличие } \\
\text { туристской инфраструк- } \\
\text { туры, следов пребыва- } \\
\text { ния человека и } \\
\text { туристских троп }\end{array}$ \\
\hline Доступность & $\begin{array}{l}\text { Только авиатранс- } \\
\text { портом }\end{array}$ & $\begin{array}{l}\text { Наземным гусеничным } \\
\text { транспортом, квадро- } \\
\text { циклами, зимой - сне- } \\
\text { гоходами }\end{array}$ & $\begin{array}{l}\text { Высокопроходимым } \\
\text { и большегрузным } \\
\text { транспортом }\end{array}$ & $\begin{array}{l}\text { Легковыми автомоби- } \\
\text { лями. Дороги - грунто- } \\
\text { вые и асфальтовые }\end{array}$ \\
\hline Климат & $\begin{array}{l}\text { Возможность органи- } \\
\text { зации путешествий от } \\
1 \text { до } 3 \text { мес. в году }\end{array}$ & $\begin{array}{l}\text { Возможность органи- } \\
\text { зации путешествий от } \\
4 \text { до } 6 \text { мес.в году }\end{array}$ & $\begin{array}{l}\text { Возможность органи- } \\
\text { зации путешествий от } \\
7 \text { до } 9 \text { мес. в году }\end{array}$ & $\begin{array}{l}\text { Возможностью органи- } \\
\text { зации путешествий от } 10 \\
\text { до } 12 \text { мес. в году }\end{array}$ \\
\hline Рельеф & $\begin{array}{l}\text { Перепады высот от } 0 \\
\text { до } 100 \text { м с отсутствием } \\
\text { обзорных точек. Абсо- } \\
\text { лютная высота мест- } \\
\text { ности от } 0 \text { до } 200 \text { м. }\end{array}$ & $\begin{array}{l}\text { Перепады высот от } 100 \\
\text { до } 500 \text { м. Абсолютная } \\
\text { высота до } 1000 \text { м. }\end{array}$ & $\begin{array}{l}\text { Перепады высот от } 500 \\
\text { до } 1000 \text { м. Абсолютная } \\
\text { высота до } 1000 \text { м или } \\
\text { более } 3000 \text { м. Районы } \\
\text { среднегорья и высоко- } \\
\text { горья. }\end{array}$ & $\begin{array}{l}\text { Перепады высот более } \\
1000 \text { м. Абсолютная } \\
\text { высота от } 1000 \text { до } 3000 \text { м. } \\
\text { Районы среднегорья. }\end{array}$ \\
\hline $\begin{array}{l}\text { Пейзажная при- } \\
\text { влекательность }\end{array}$ & $\begin{array}{l}\text { Однородные и моно- } \\
\text { тонные пейзажи с } \\
\text { преобладанием чер- } \\
\text { ного и серого цветов, } \\
\text { с залесенностью от } 0 \\
\text { до } 10 \% \text { или зеленого } \\
\text { цвета, если залесен- } \\
\text { ность от } 91 \text { до 100\%, } \\
\text { без выделяющегося } \\
\text { объекта, с одноплано- } \\
\text { вым видом }\end{array}$ & $\begin{array}{l}\text { Разнообразный, но } \\
\text { одноплановый пейзаж } \\
\text { со слабо выраженным } \\
\text { выделяющимся объек- } \\
\text { том, с преобладанием } \\
\text { светло-серого, корич- } \\
\text { невого и палевого } \\
\text { цвета, с залесенностью } \\
\text { от } 11 \text { до 20\% или зеле- } \\
\text { ного цвета, если зале- } \\
\text { сенность от } 81 \text { до } 90 \%\end{array}$ & $\begin{array}{l}\text { Разнообразный мно- } \\
\text { гоплановый пейзаж } \\
\text { голубого и зеленого } \\
\text { цвета с сильно выра- } \\
\text { женным выделяю- } \\
\text { щимся объектом } \\
\text { и залесенностью от } 21 \\
\text { до 30\% и от } 71 \text { до } 80 \%\end{array}$ & $\begin{array}{l}\text { Разнообразный много- } \\
\text { плановый пейзаж } \\
\text { бирюзового, желтого, } \\
\text { белого, розового, } \\
\text { синего, красного цвета, } \\
\text { с несколькими выделя- } \\
\text { ющимися объектами со } \\
\text { степенью залесенности } \\
\text { от } 31 \text { до 70\% }\end{array}$ \\
\hline
\end{tabular}

Каждый критерий из пяти может иметь максимальное значение 4 балла, соответственно, максимальное значение Рпрс равно 20 баллам, а минимальное - 5 баллам. В табл. 2 произведено ранжирование критериев оценки рекреационного потенциала.

Наиболее удобным способом оценки рекреационного потенциала ПРС являются ГИС-технологии и метод картографирования. Построение карт в программе ArcGIS позволяет оценить каждый показатель и проанализировать его. После этого вычисляются баллы по каждому из показателей, затем с помощью наложения карт и суммирования баллов создается итоговая карта, оценивающая рекреационный потенциал ПРС на территории выбранного региона.

Гипотетически, самый низкий балл может быть присвоен территории, расположенной в труднодоступном месте, без выраженного рельефа, севернее полярного круга, где недавно осу- ществлялись шахтные разработки. Градацию рекреационного потенциала можно произвести следующим образом: 1-5 баллов - очень низкий уровень, 6-10 баллов - низкий уровень, 11-15 баллов - средний уровень, 16-20 баллов - высокий уровень рекреационного потенциала ПРС.

Таким образом, изучение рекреационного потенциала ПРС какой-либо территории способствует наиболее эффективному и логичному развитию природоориентированного туризма в данном регионе.

\section{ОЦЕНКА РЕКРЕАЦИОННОГО ПОТЕНЦИАЛА ПРС АРЕАЛОВ НЕДОСТУПНОСТИ ПЕРМСКОГО КРАЯ}

Описанная методика была применена нами для оценки рекреационного потенциала ареалов недоступности микроуровня, окружающих город Пермь. Все эти ареалы одинаковы по рекреаци- 
Таблица 3. Рекреационный потенциал ПРС ареала полюса недоступности Пермского края

\begin{tabular}{l|c|c|c|c|c}
\hline \multicolumn{1}{c|}{ Показатель } & 13 баллов & 14 баллов & 15 баллов & 16 баллов & 17 баллов \\
\hline Площадь, км \\
\% от площади ареала недоступности & 12810 & 11980 & 5560 & 4150 & 970 \\
\hline
\end{tabular}

онным возможностям, так как расположены рядом друг с другом. По критерию хозяйственной деятельности $(\mathrm{X})$ все они получили 3 балла: массовая хозяйственная деятельность в пригородных лесах велась более 30 лет назад, но в связи с тем, что рядом находится крупный населенный пункт, отдельные участки подвергаются таковой постоянно. Доступность (Д) оценена максимальным количеством баллов - 4. Климатические условия (K) изучаемых участков соответствуют таковым для всего региона: активная туристская деятельность массово осуществляется здесь 6-7 мес. в году, с начала февраля до конца марта и с начала мая до конца сентября. Однако в ареалах недоступности, окружающих Пермь, в основном осуществляется однодневная рекреационная деятельность, без ночевок. При этом нет таких жестких условий, как при осуществлении активных туристских путешествий продолжительностью в несколько дней, соответственно, здесь рекреация может быть круглогодичной, хотя во многие месяцы довольно некомфортной. Климатические условия оценены в 4 балла. По показателю рельефа (Р) данные объекты получают 1 балл в виду того, что перепады высот в пределах 50 м, а абсолютная высота - менее 200 м. По пейзажной привлекательности (П) - 2 балла, потому что пейзажи в окрестностях Перми, как правило, одноплановые, но разнообразные и с залесенностью более $80 \%$. Итак, рекреационный потенциал ареалов недоступности вокруг Перми, рассчитанный по предложенной формуле, составил 14 баллов, что относится к среднему уровню.

На территории Пермского края существуют также ареалы недоступности мезоуровня. Самый большой из них окружает полюс недоступности края, расположенный, как говорилось выше, на северо-востоке региона. Площадь этого ареала, затрагивающего еще и участки Республики Коми и Свердловской области, составляет 55810 км², в

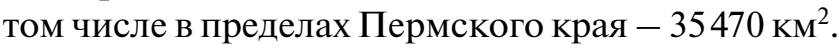
Здесь целиком располагается заповедник “Вишерский”, а также территории с разными значениями показателей рельефа, доступности, хозяйственной деятельности и пейзажной привлекательности. Оценка больших пространств осуществлялась по описанной выше методике с помощью программы ArcGIS. Расчеты проведены только для части ареала недоступности, расположенной на территории Пермского края.
По критерию транспортной доступности в данном ареале присутствуют только участки, до которых можно добраться специализированным автотранспортом, вездеходной и авиационной техникой, что соответствует 1-3 баллам (рис. 3). При этом от старых, редко посещаемых дорог, подходящих к ареалу недоступности, была очерчена десятикилометровая буферная зона - расстояние, которое могут пройти туристы за один день. По критерию хозяйственной деятельности в границах ареала существуют только территории с отсутствием таковой или с давними следами хозяйственного воздействия, что соответствует 3-4 баллам (рис. 4). Наиболее точно определить, какие территории подвергались ей, а какие нет, можно с помощью космоснимков.

По критерию климат на всей территории Пермского края, а соответственно и в ареале недоступности, массовая туристская деятельность возможна 7 мес. в году, что соответствует 3 баллам. По критерию рельеф в ареале недоступности присутствуют участки с перепадами высот от 100 до 1000 м и более, что соответствует 2-4 баллам (рис. 5). В исследуемом ареале недоступности благодаря наличию на его территории гор Северного Урала и большого количества рек присутствуют только высокоаттрактивные участки со значениями пейзажной привлекательности 3 и 4 балла (рис. 6).

Суммирование всех критериев, показало, что рекреационный потенциал ПРС на участке изучаемого ареала недоступности на территории Пермского края соответствует среднему и высокому уровням (рис. 7, табл. 3).

\section{ЗАКЛЮЧЕНИЕ}

1. На ненаселенных территориях выделяются точки - полюсы недоступности, максимально удаленные от любой инфраструктуры, вокруг которых формируются ареалы недоступности, со всех сторон ограниченные разными инфраструктурными объектами.

2. Можно выделять полюсы недоступности разного масштаба: муниципального (микроуровня), регионального (мезоуровня), национальноконтинентального (макроуровня) и планетарного (мегауровня). В каждом из них складывается особенная система организации рекреации и туризма. 


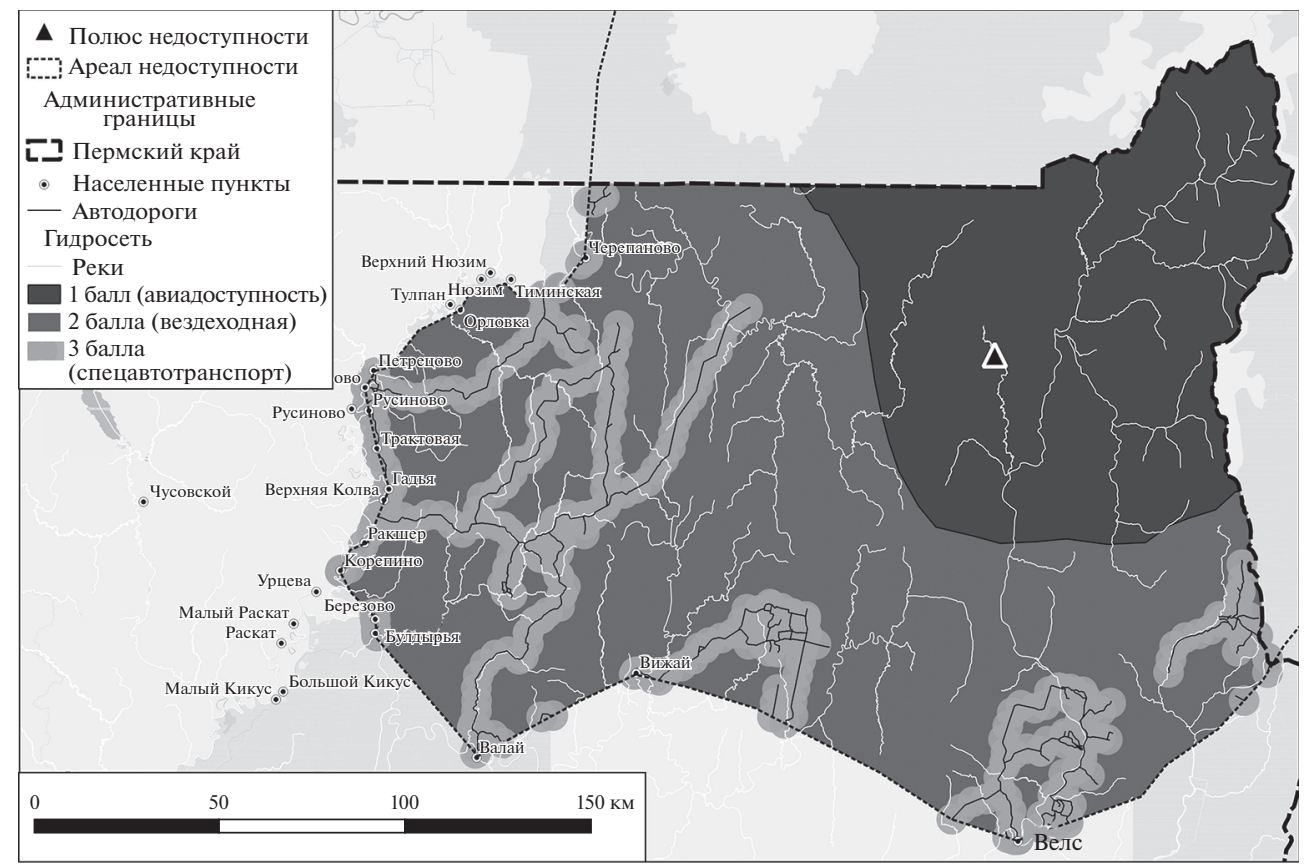

Рис. 3. Транспортная доступность на территории ареала полюса недоступности Пермского края.

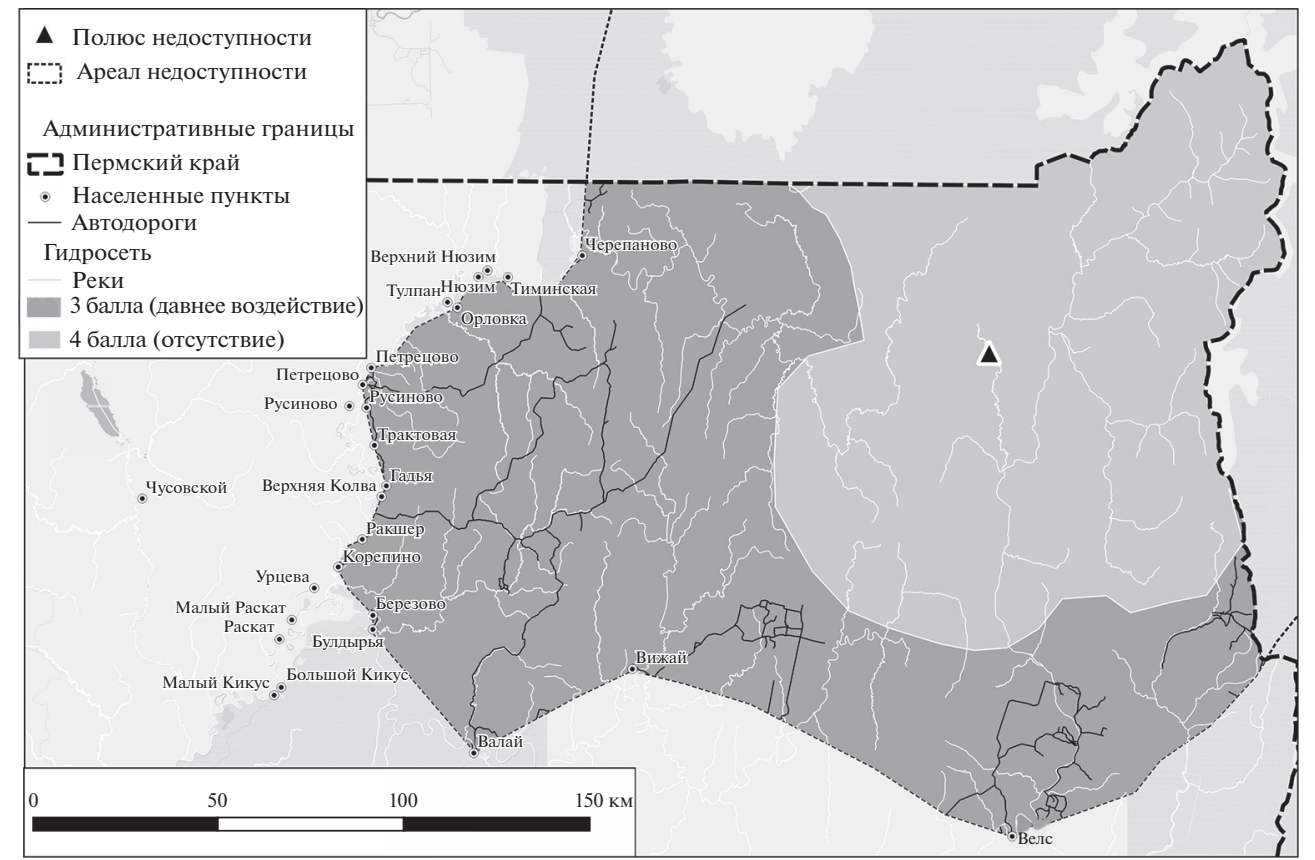

Рис. 4. Хозяйственная деятельность на территории ареала полюса недоступности Пермского края.

3. Природная рекреационная система (ПРС) это совокупность разных по функциям элементов, определяющих рекреацию в ареалах недоступности, и отражающая взаимодействие туристов и рекреантов, ненаселенных природных территорий и контролирующих органов, осуществляющих регистрацию, поиск и спасение туристских групп на ненаселенных территориях.

4. Для вычисления рекреационного потенциала ПРС предложена формула: 


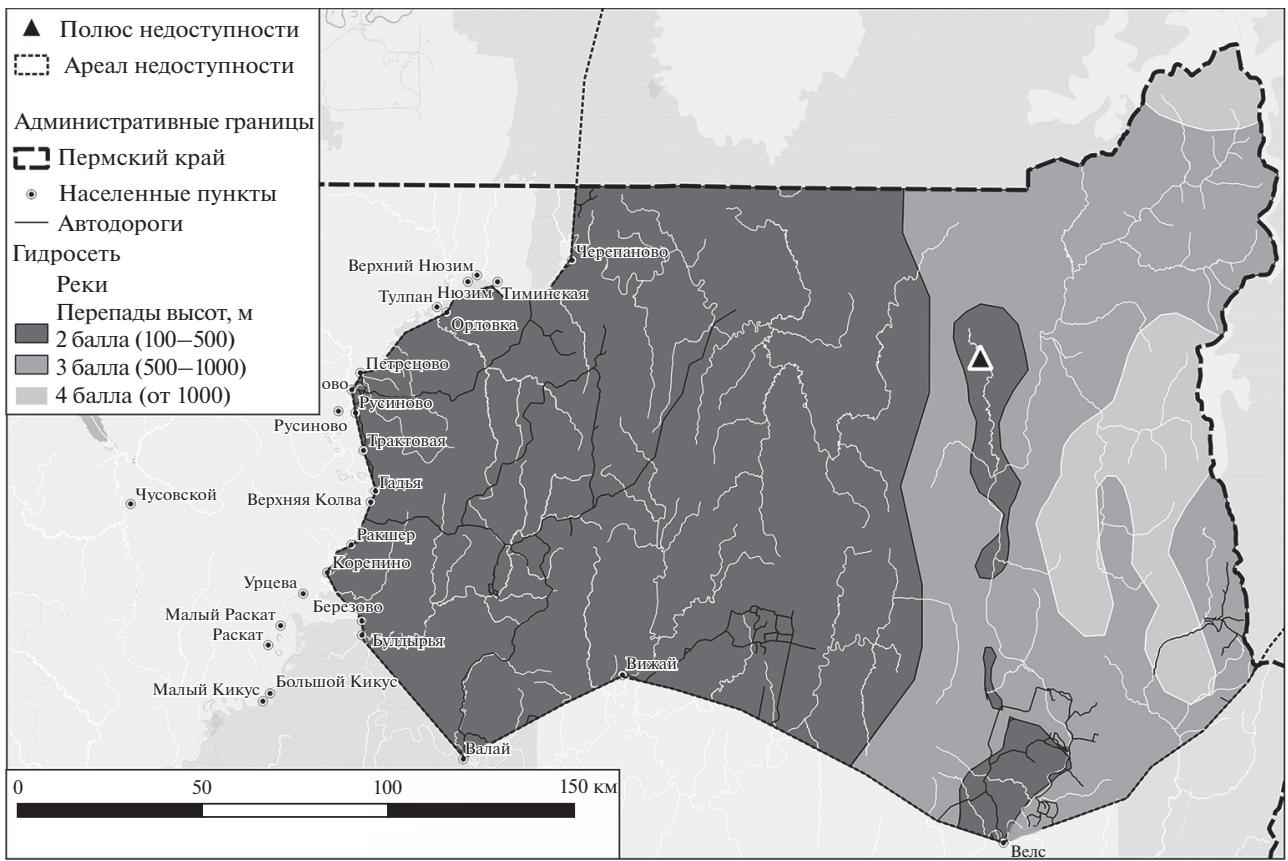

Рис. 5. Рельеф на территории ареала полюса недоступности Пермского края.

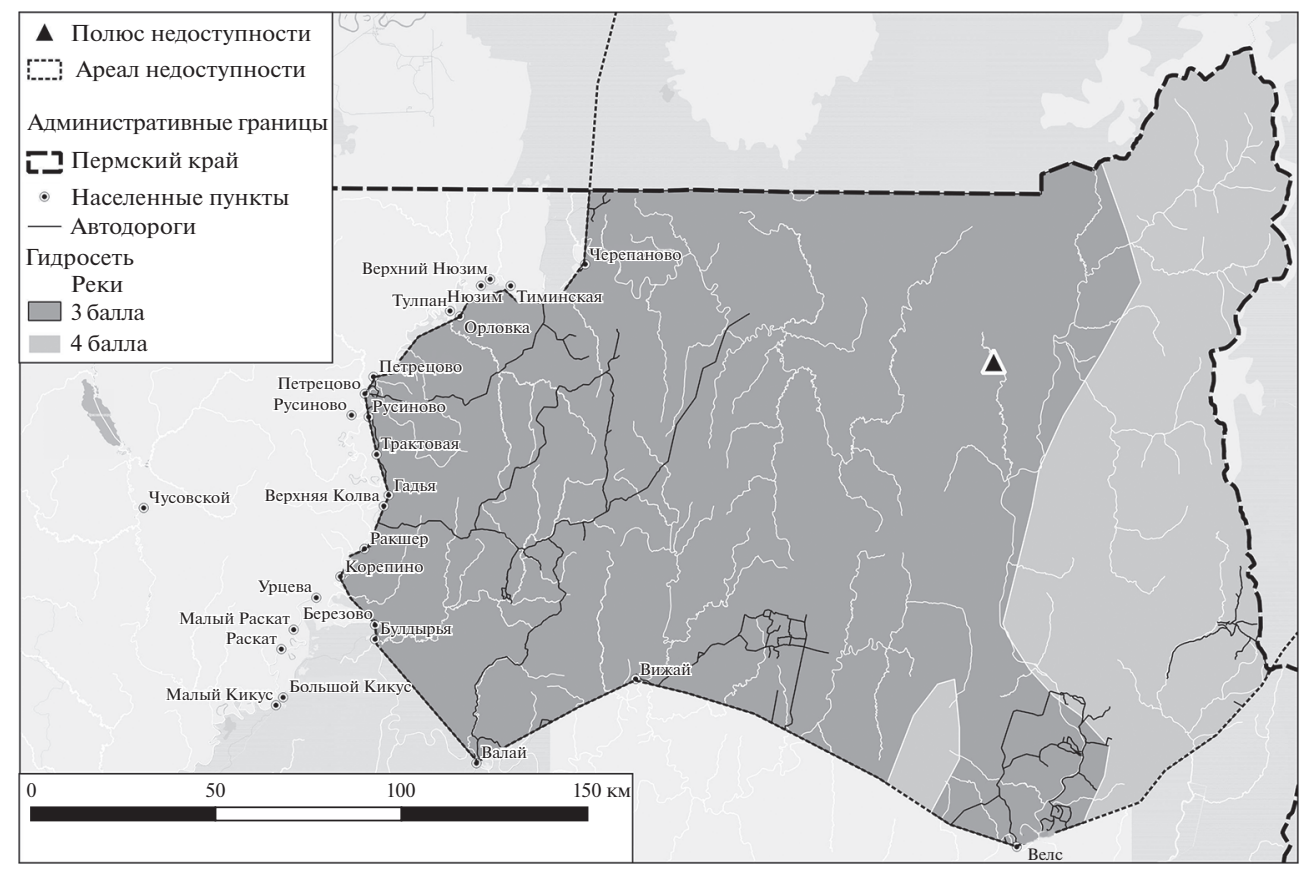

Рис. 6. Пейзажная привлекательность на территории ареала полюса недоступности Пермского края.

Рпрс $=$ X + Д + K + + P + П,

где $\mathrm{X}$ - хозяйственная деятельность, Д - доступность, $\mathrm{K}$ - климат, $\mathrm{P}$ - рельеф, П - пейзажная привлекательность.

5. Рекреационный потенциал ПРС ареалов недоступности микроуровня, окружающих город Пермь, полученный с помощью данной форму- лы, составил 14 баллов, что соответствует среднему уровню.

6. Исследование ареала полюса недоступности Пермского края (мезоуровня) проведено с помощью данной формулы, а также с использованием ГИС-технологий. Рекреационный потенциал ПРС 


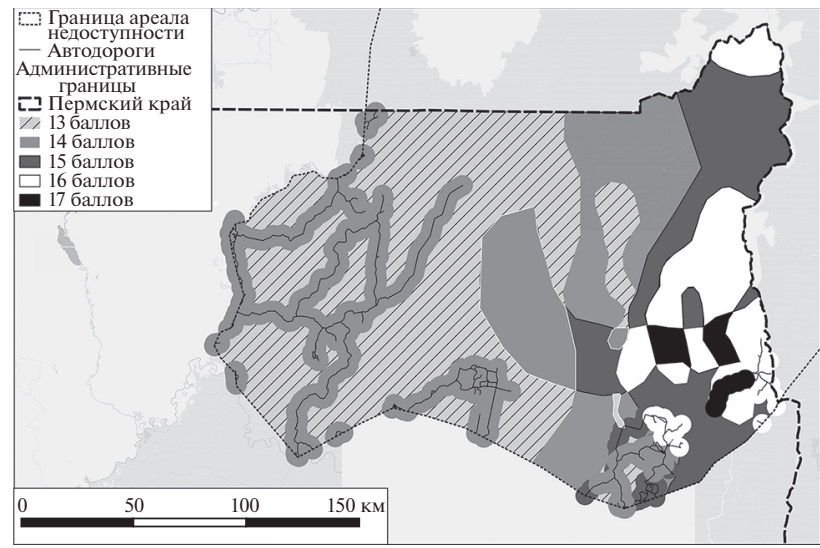

Рис. 7. Оценка ПРС на территории ареала полюса недоступности Пермского края.

для ареала составил от 13 до 17 баллов, что соответствует среднему и высокому уровням.

Таким образом можно оценить ареалы недоступности всех уровней. При этом имеются взаимоисключающие и взаимодополняющие критерии. К первым относятся критерии хозяйственной деятельности и доступности: чем доступнее местность, тем сильнее на ней выражена хозяйственная деятельность, и наоборот. Ко вторым принадлежат критерии рельефа и пейзажной привлекательности: если по рельефу местность имеет высокий балл, значит, находится в районах среднегорья с соответствующими перепадами высот. Именно в таких местностях складываются наиболее красивые и эстетически наполненные пейзажи.

Проведение оценки рекреационного потенциала отдельных участков ПРС в каком-либо регионе позволяет выявить территории, наиболее перспективные с точки зрения развития рекреационной и туристской деятельности и создания ООПТ.

\section{СПИСОК ЛИТЕРАТУРЫ}

1. Адашова T.A. Антарктида глазами туриста // Coвременные проблемы сервиса и туризма. 2014. № 1. C. 53-60.

2. Алексеев С.С. Цветоведение. М.: Искусство, 1973. $148 \mathrm{c}$.

3. Арманд Д.Л. Балльные шкалы в географии // Изв. АН СССР. Сер. геогр. 1973. № 2. С. 11-24.

4. Барышников А.П. Перспектива. М.: Искусство, 1955. $200 \mathrm{c}$.

5. Богданов Е.И., Кострюкова О.Н., Орловская В.П., Фенин П.М. Планирование на предприятии туризма: учеб. пособие для вузов. СПб.: Изд. дом Бизнес-пресса 2, 2003. 288 с.

6. Веденин Ю.А., Мирошниченко Н.Н. Оценка природных условий для организации отдыха // Изв. АН СССР. Сер. геогр. 1969. № 4. С. 51-60.
7. Величковский Б.М. Современная когнитивная психология. М.: Изд. Моск. ун-та, 1982. 336 с.

8. Джанджугазова Е.А. Формирование стратегии развития регионального туристско-рекреационного комплекса: Дис. ... Д-ра экон. наук. М., 2005. 204 с.

9. Дирин Д.А. Оценка и рекреационное использование пейзажно-эстетических ресурсов Усть-Коксинского района Республики Алтай. Новосибирск: ИВЭП СО РАН, 2007. $206 \mathrm{c.}$

10. Дирин Д.А., Попов Е.С., Николаева О.П. Эстетикорекреационные ресурсы горной части Алтайского края // Мир науки, культуры, образования. 2010. № 6-1. C. 262-269.

11. Дроздов A.B. Туристские ресурсы и туристский продукт национальных парков России. М.: ЭкоЦентр “Заповедники”, 2000. 61 с.

12. Зырянов А.И., Миролюбова Т.В. Методологические подходы к исследованию развития региона с позиций новой экономической и теоретической географии // Изв. РАН. Сер. геогр. 2014. № 5. С. 23-31.

13. Зырянов А.И., Мышлявцева С.Э. Туристские кластеры и доминанты (на примере Пермского края) // Изв. РАН. Сер. геогр. 2012. № 2. С. 13-20.

14. Исаченко А.Г. Методы прикладных ландшафтных исследований. Л.: Наука, 1980. 224 с.

15. Колбовский Е.Ю. Экологический туризм и экология туризма: Учеб. пособие для студ. высш. учеб. заведений. М.: Академия, 2006. 256 с.

16. Королев А.Ю. Географические особенности полюсов недоступности Северного полушария Земли // Вестн. Удм. ун-та. Сер. Биология. Науки о Земле. 2012. № 2. C. 149-152.

17. Королев А.Ю. Полюсы недоступности Пермского края // Региональные исследования. 2014. № 1. C. $130-132$.

18. Котляров E.A. География отдыха и туризма. М., 1978. $240 \mathrm{c}$.

19. Мельников И.А. К полюсу относительной недоступности // Природа. 2013. № 7 (1175). С. 92-96.

20. Мироненко Н.С., Твердохлебов И.Т. Рекреационная география. М.: Изд-во Моск. ун-та, 1981. 207 с.

21. Мухина Л.И., Савельева В.В. Особенности рекреационной оценки среднегорной территории (на примере Архыза) // Изв. АН СССР. Сер. геогр. 1973. № 1. С. 95-102.

22. Мышлявцева С.Э. Туристско-рекреационное обоснование создания природного парка "Усьвинский” на территории Гремячинского и Чусовского районов Пермского края // Геогр. вестник. 2012. № 4 (23). C. 89-96.

23. Нефедова В.Б., Смирнова Е.Д., Швидченко Л.Г. Методы рекреационной оценки территорий // Вестн. Моск. ун-та. Сер. 5. География, 1973. № 5. С. 4954.

24. Николаев В.А. Эстетическое восприятие ландшафта // Вестн. Моск. ун-та. Сер. 5: География. 1999. № 6. C. $10-15$.

25. Николаев В.А. Ландшафтоведение: эстетика и дизайн. М.: Аспект Пресс, 2003. 176 с.

26. Преображенский В.С., Веденин Ю.А. География и отдых: изучение организации и планирования зон отдыха. М.: Знание, 1971. 48 с. 
27. Преображенский В.С., Веденин Ю.А., Зорин И.В., Мухина Л.И. Территориальная рекреационная система как объект изучения географических наук // Изв. АН СССР. Сер. геогр. 1974. № 2. С. 34-42.

28. Родоман Б.Б. Поляризованная биосфера. Смоленск: Ойкумена, 2002. 336 с.

29. Сафарян A.A. Особенности туристских исследований в горных регионах мира // Геогр. вестник. 2015. № 2 (33). С. 110-116.

30. Сафарян A.A. Подходы к оценке туристского потенциала территорий // Геогр. вестник. 2015. № 1 (32). C. 89-102.

31. Супруненко Ю.П. Горы зовут... (Горно-рекреационное природопользование). М.: Тровант, 2003. $368 \mathrm{c}$.

32. Талалай П.Г., Марков А.Н. Горы Гамбурцева - хребет, который никто никогда не видел // Природа. 2012. № 2(1158). С. 29-38.

33. Тарасов А.Н. Опыт туристской классификации лесов Кавказа // Вопросы развития туризма. Сухуми, 1973. C. 28-33.

34. Теоретические основы рекреационной географии / под ред. В.С. Преображенского. М., 1975. 223 с.

35. Тхамитлокова Ю.О. Методические подходы к оценке и анализу ресурсного потенциала сферы туризма и рекреации // Научный форум: Экономика и менеджмент: Сб. ст. по материалам IV междунар. науч.-практ. конф. № 2 (4). М.: Изд. "МЦHO”, 2017. C. 49-55.

36. Файбусович Э.Л., Чечетова Л.В. Методика оценки природных условий для туризма // Краеведение и туризм. Л., 1973. С. 3-15.

37. Фролова М.Ю. Оценка эстетических достоинств природных ландшафтов // Вестн. Моск. ун-та. Сер. 5: География. 1994. № 2. С. 27-33.

38. Худеньких Ю.А. Подходы к оценке туристского потенциала территории на примере районов Перм- ского края // География и туризм. 2006. № 2. C. 217-230.

39. Чибилёва В.П. Оценка рекреационного потенциала южных районов Оренбургской области в контексте пространственного планирования // Вестн. Оренб. ун-та. 2011. № 12 (131). С. 268-269.

40. Эрингис К.И., Будрюнас А.-Р.А. Сущность и методика детального эколого-эстетического исследования пейзажей // Экология и эстетика ландшафта. Вильнюс: Минтис, 1975. С. 107-170.

41. Allan J.R. et al. Recent increases in human pressure and forest loss threaten many Natural World Heritage Sites // Biol. Conserv. 2017. № 206. P. 47-55.

42. Fines K.D. Landscape evaluation: a research project in East-Sassux // Reg. Stud. 1968. V. 2. № 1. P. 41-55.

43. Gorelick N. et al. Google Earth Engine: planetary-scale geospatial analysis for everyone // Remote Sens. Environ. 2017. № 202. P. 18-27.

44. Hansen M.C. et al. High-resolution global maps of 21 stcentury forest cover change // Science. 2013. № 342. P. 850-853.

45. Ibisch P.L. et al. A global map of roadless areas and their conservation status // Science. 2016. № 354. P. 14231427.

46. Linton D.L. The assesment of scenery as a natural resource // Scotish Geogr. Mag. 1968. № 84. P. 219-238.

47. Nelson A. Travel time to major cities: a global map of accessibility. Luxembourg: Office for Official Publications of the European Communities, 2008. doi: 10.2788/95835.

48. Ribeiro J.C., Vareiro L.C. The Tourist Potential of the Minho-Lima Region (Portugal). Visions for Global Tourism Industry // Creating and Sustaining Competitive Strategies. 2012. P. 339-356.

49. Weiss D.J., Nelson A., Gibson H.S. A global map of travel time to cities to assess inequalities in accessibility in 2015 // Nature. 2018. № 553. P. 333-336.

\title{
Assessment of Natural Recreational System in the Areas of Inaccessibility
}

\author{
A. Yu. Korolev ${ }^{\#}$ \\ Perm State University, Perm, Russia \\ \#e-mail:korolev@psu.ru
}

In uninhabited territories points are allocated-the poles of inaccessibility-maximum remoted from any infrastructure. Around them the areas of inaccessibility are formed, on all sides limited by different infrastructural objects. The poles of inaccessibility can be allocated to different scales: municipal, regional, nationalcontinental and planetary. In each of them there is a special system for organizing recreation. The set of elements of recreation, which are different in function, determines the recreation in the areas of inaccessibility and constitutes the natural recreation system. It reflects interaction of tourists and recreationists, unpopulated natural territories and controlling bodies that register, search and rescue tourist groups. In the article the formula to calculate the recreational potential of the natural recreation system was formulated. It takes into account economic activity, accessibility, climate, relief, and landscape attractiveness. The maximum value of natural recreation system' potential is equal to 20 points (each criterion of five may have a maximum value of 4 points). The areas of inaccessibility of the microlevel surrounding Perm were studied. Their recreational potential of the natural recreation system was 14 points, which corresponds to the average level. The area of the inaccessibility of the Perm krai was also investigated. Its recreational potential ranged from 13 to 17 points, which corresponds to the average and high levels. Using the formula and GIS technology allows to determine territories for development recreational and tourist activities and creating protected natural areas.

Keywords: pole of inaccessibility, tourism, recreation, territorial recreational system, natural areas, Perm krai, landscape attractiveness, economic activity 


\section{REFERENCES}

1. Adashova T.A. Antarctica through the eyes of a tourist. Sovrem. Probl. Servisa i Turizma, 2014, no. 1, pp. 53-60. (In Russ.).

2. Alekseev S.S. Tsvetovedenie [Color Science]. Moscow: Iskusstvo Publ., 1973. 148 p.

3. Armand D.L. Point scales in geography. Izv. Akad. Nauk, Ser. Geogr., 1973, no. 2, pp. 11-24. (In Russ.).

4. Baryshnikov A.P. Perspektiva [Perspective]. Moscow: Iskusstvo Publ., 1955. 200 p.

5. Bogdanov E.I., Kostryukova O.N., Orlovskaya V.P., Fenin P.M. Planirovanie na predpriyatii turizma: ucheb. posobie dlya vuzov [Planning for Tourism Companies: the Handbook for University Students]. St. Petersburg: Dom Biznes-Pressa 2 Publ., 2003. 288 p.

6. Vedenin Yu.A., Miroshnichenko N.N. Assessment of natural conditions for recreation. Izv. Akad. Nauk, Ser. Geogr., 1969, no. 4, pp. 51-60. (In Russ.).

7. Velichkovskii B.M. Sovremennaya kognitivnaya psikhologiya [Modern Cognitive Psychology]. Moscow: Mosk. Gos. Univ., 1982. 336 p.

8. Dzhandzhugazova E.A. Formation of the development strategy of the regional tourist and recreational complex. Doctoral (Econ.) Dissertation. Moscow: Moscow State Univ., 2005. 204 p.

9. Dirin D.A. Otsenka i rekreatsionnoe ispol'zovanie peizazhno-esteticheskikh resursov Ust'-Koksinskogo raiona Respubliki Altai [Evaluation and Recreational Use of Landscape-Aesthetic Resources of the Ust-Koksinsky District of the Altai Republic]. Novosibirsk: Inst. Vodn. Ekol. Probl. Sib. Otd. Akad. Nauk, 2007. 206 p.

10. Dirin D.A., Popov E.S., Nikolaeva O.P. Aesthetic-recreation resources in mountainous part of Altai krai. Mir Nauki, Kul'tury, Obrazovaniya, 2010, no. 6-1, pp. 262269. (In Russ.).

11. Drozdov A.V. Turistskie resursy i turistskii produkt natsional'nykh parkov Rossii [Tourist Resources and Tourist Product of National Parks of Russia]. Moscow: EkoTsentr "Zapovedniki", 2000. 61 p.

12. Zyryanov A.I., Mirolyubova T.V. Methodological approaches to the study of development of the region from the perspective of new economic and theoretical geography. Izv. Akad. Nauk, Ser. Geogr., 2014, no. 5, pp. 2331. (In Russ.).

13. Zyryanov A.I., Myshlyavtseva S.E. Touristic clusters of Perm krai. Izv. Akad. Nauk, Ser. Geogr., 2012, no. 2, pp. 13-20. (In Russ.).

14. Isachenko A.G. Metody prikladnykh landshaftnykh issledovanii [Methods of Applied Landscape Research]. Leningrad: Nauka Publ., 1980. 224 p.

15. Kolbovskii E.Yu. Ekologicheskii turizm i ekologiya turizma: ucheb. posobie dlya stud. vyssh. ucheb. zavedenii [Ecotourism and Ecology of Tourism: the Handbook for University Students]. Moscow: Akademiya Publ., 2006. $256 \mathrm{p}$.

16. Korolev A.Yu. Geographical features of inaccessibility poles of Northern Hemisphere of the Earth. Vestn. Udmurtskogo Univ., Ser. Biol. Nauki o Zemle, 2012, no. 2, pp. 149-152. (In Russ.).

17. Korolev A.Yu. Inaccessibility poles of the Perm krai. Reg. Issled., 2014, no. 1, pp. 130-132. (In Russ.).
18. Kotlyarov E.A. Geografiya otdykha i turizma [Geography of Recreation and Tourism]. Moscow, 1978. 240 p.

19. Mel'nikov I.A. To the pole of relative inaccessibility. Priroda, 2013, no. 7 (1175), pp. 92-96. (In Russ.).

20. Mironenko N.S., Tverdokhlebov I.T. Rekreatsionnaya geografiya [Recreational Geography]. Moscow: Mosk. Gos. Univ., 1981. 207 p.

21. Mukhina L.I., Savel'eva V.V. Features of the recreational assessment of the midland areas (on the example of Arkhyz). Izv. Akad. Nauk, Ser. Geogr., 1973, no. 1, pp. 95-102. (In Russ.).

22. Myshlyavtseva S.E. Tourist and recreational justification for the creation of the Usvinsky Natural Park in the Gremyachinsky and Chusovsky districts of the Perm krai. Geogr. Vestn., 2012, no. 4(23), pp. 89-96. (In Russ.).

23. Nefedova V.B., Smvirnova E.D., Shvidchenko L.G. Methods of recreational assessment of territories. Vestn. Mosk. Univ., Ser. 5: Geogr, 1973, no. 5, pp. 49 -54. (In Russ.).

24. Nikolaev V.A. Aesthetic perception of the landscape. Vestn. Mosk. Univ., Ser. 5: Geogr., 1999, no. 6, pp. 1015. (In Russ.).

25. Nikolaev V.A. Landshaftovedenie: estetika $i$ dizain [Landscape Science: Aesthetics and Design]. Moscow: Aspekt Press Publ., 2003. 176 p.

26. Preobrazhenskii V.S., Vedenin Yu.A. Geografiya $i$ otdykh: izuchenie organizatsii i planirovaniya zon otdykha [Geography and Recreation: The Study of the Organization and Planning of Recreation Areas]. Moscow: Znanie Publ., 1971. 48 p.

27. Preobrazhenskii V.S., Vedenin Yu.A., Zorin I.V., Mukhina L.I. Territorial recreational system as an object of study of geographical sciences. Izv. Akad. Nauk, Ser. Geogr., 1974, no. 2, pp. 34-42. (In Russ.).

28. Rodoman B.B. Polyarizovannaya biosfera [The Polarized Biosphere]. Smolensk: Oikumena Publ., 2002. 336 p.

29. Safaryan A.A. Special features of tourism studies in the mountain regions of the world. Geogr. Vestn., 2015, no. 2(33), pp. 110-116. (In Russ.).

30. Safaryan A.A. Approaches to the estimation of the tourism potential of the territory. Geogr. Vestn., 2015, no. 1(32), pp. 89-102. (In Russ.).

31. Suprunenko Y.P. Gory zovut... (Gorno-rekreatsionnoe prirodopol'zovanie) [The Mountains are Calling ... (Mountain and Recreational Use of Nature)]. Moscow: Trovant Publ., 2003. 368 p.

32. Talalai P.G., Markov A.N. The Gamburtsev Mountains - a ridge that no one has ever seen. Priroda, 2012, no. 2 (1158), pp. 29-38. (In Russ.).

33. Tarasov A.N. Experience in tourist classification of Caucasian forests. In Vopr. Razvitiya Turizma [Problems of Tourism Development]. Sukhumi, 1973, pp. 28-33. (In Russ.).

34. Teoreticheskie osnovy rekreatsionnoi geografii [Theoretical Foundations of Recreational Geography]. Moscow: Nauka Publ., 1975. 223 p.

35. Tkhamitlokova Yu.O. Methodological approaches to assessing and analyzing the resource potential of tourism and recreation. In Nauchn. forum: Ekonomika $i$ menedzhment: sb. st. po materialam IV mezhdunar. 
nauchn.-prakt. konf [Sci. Forum: Economics and Management: Materials of the IV Int. Sci.-Practical Conf.], no. 2(4). Moscow: MTsNO Publ., 2017, pp. 49-55. (In Russ.).

36. Faibusovich E.L., Chechetova L.V. Methods for assessing the natural conditions for tourism. In Kraevedenie $i$ Turizm [Local History and Tourism]. Leningrad, 1973, pp. 3-15. (In Russ.).

37. Frolova M.Yu. Evaluation of the aesthetic advantages of natural landscapes. Vestn. Mosk. Univ., Ser. 5: Geogr., 1994, no. 2, pp. 27-33. (In Russ.).

38. Khuden'kikh Yu.A. Approaches to the assessment of the tourist potential of the territory on the example of areas of the Perm krai. Geografija i Turizm, 2006, no. 2, pp. 217-230. (In Russ.).

39. Chibileva V.P. Assessment of the recreational potential of the southern regions of the Orenburg oblast in the context of spatial planning. Vestn. Orenburg. Gos. Univ., 2011, no. 12(131), pp. 268-269. (In Russ.).

40. Eringis K.I., Budryunas A.-R.A. The essence and methods of detailed ecological and aesthetic research of landscapes. In Ekologiya i Estetika Landshafta [Ecology and Aesthetics of Landscape]. Vilnius: Mintis Publ., 1975, pp. 107-170. (In Russ.).

41. Allan J.R., Venter O., Maxwell S., Bertzky B., Jones K., Shi Y., Watson J.E. Recent increases in human pressure and forest loss threaten many Natural World Heritage Sites. Biol. Conserv., 2017, vol. 206, pp. 47-55.
42. Fines K.D. Landscape evaluation: a research project in East-Sassex. Reg. Stud., 1968, vol. 2, no. 1, pp. 41-55.

43. Gorelick N., Hancher M., Dixon M., Ilyushchenko S., Thau D., Moore R. Google Earth Engine: planetaryscale geospatial analysis for everyone. Remote Sens. Environ, 2017, vol. 202, pp. 18-27.

44. Hansen M.C. et al. High-resolution global maps of 21st-century forest cover change. Science, 2013, vol. 342, pp. 850-853. doi: 10.1126/science. 1244693

45. Ibisch P.L. et al. A global map of roadless areas and their conservation status. Science, 2016, vol. 354, pp. 1423-1427. doi: 10.1126/science.aaf7166

46. Linton D.L. The assesment of scenery as a natural resource. Scott. Geogr. Mag., 1968, vol. 84, no. 3, pp. 219238.

47. Nelson A. Travel Time to Major Cities: a Global Map of Accessibility. Luxembourg: Office for Official Publications of the European Communities, 2008. doi: $10.2788 / 95835$

48. Ribeiro J.C., Vareiro L.C. The tourist potential of the Minho-Lima region (Portugal). In Visions for Global Tourism Industry: Creating and Sustaining Competitive Strategies. Kasimoglu M., Ed. BoD-Books on Demand, 2012, pp. 339-356.

49. Weiss D.J. et al. A global map of travel time to cities to assess inequalities in accessibility in 2015. Nature, 2018, vol. 553, pp. 333-336. doi: 10.1038/nature25181 